\title{
Integrated Disease Management of Tomato Late Blight ${ }^{1}$
}

\author{
Krishna K. Shrestha ${ }^{1}$ and Richard Ashley ${ }^{2}$ \\ ${ }^{1}$ Plant Pathology Division, Nepal Agricultural Research Council, Khumaltar, \\ Lalitpur, Nepal<krishnak85@,hotmail.com $>$ \\ ${ }^{2}$ Department of Plant Science, University of Connecticut, USA
}

\begin{abstract}
Tomato late blight caused by Phytophthora infestans (Mont.) de Bary is a serious disease of tomato and potato worldwide. The disease causes severe crop losses in the tomato growing regions of the world. Most of the cultivars grown in the world are reported to be susceptible to late blight. Systemic fungicides have been used widely in the past, but the disease has developed resistance over time. The present study was carried out to minimize fungicide use through integrated pest management. The bio-pesticides Azadirachta indica (Neem), Artemisia vulgaris (Mugwort) and Trichoderma viride were tested along with the fungicides Krilaxyl (metalaxyl $8 \%$ and mancozeb 64\%) and Dithane M-45 (mancozeb 80\%) in Nepal during 2000 and 2001. All three bio-pesticides were found more effective than the control in reducing development of the disease and they increased yield over the control by 17 to $41 \%$. However, the fungicides, Krilaxyl and Dithane M-45 were observed even more effective. Two transplanting dates ie first and third week of July were tested against late blight in rainy season during 2000and 2001 and observed its effect on yields. Lower disease incidence and better yield were found in the second planting.
\end{abstract}

Key words: Dithane-M45, Krilaxyl, mugwort, Neem, Phytophthora infestans, Trichoderma

\section{INTRODUCTION}

Tomato late blight caused by Phytophthora infestans (Mont.) de Bary, is a destructive disease of tomato in many parts of the world. The disease also occurs commonly in potatoes, eggplant, nightshade and occasionally on peppers of the family, Solanaceae (Stevenson 1993). Wherever tomatoes are grown in tropics without excess use of fungicides, the disease is commonly present (Griffith et al 1995). The disease was reported having caused tomato and potato crops losses up to 100\% (Fry 1999, Shrestha 1999, CIP 1999, Shrestha and Shrestha 1997, Pohronezny et al 1986, Sherf and Macnab 1986). In California, United States, late blight appears in all tomato growing areas particularly in sprinkler irrigated fields during prolonged periods of rain and /or fog with mild temperatures (Nunez and Voss 2001). An outbreak of tomato late blight occurred in Ontario, Canada in 1976 (Reyes et al 1977). Since 1990, severe outbreaks of late blight have been observed in commercial and home garden crops of potato and tomato in the United States and Canada (Rowe et al 2002).

At present, no tomato cultivars in the world are grown on a commercial scale without chemical protection from late blight disease. The interval between spraying and harvesting is usually 2 to 3 days in Nepal (SK Shrestha 2002, personal communication) and 0 to 5 days in the United States (R.

\footnotetext{
${ }^{1}$ The paper is based on PhD thesis of the first author submitted to University of Connecticut (UCONN), USA.
} 
Ashley 2003, personal communication). The annual chemical application to tomato and potato crops is higher than any other food crops grown today (Niederhauser 1991). Such heavy use of pesticides could result in increased human health hazards and environmental pollution. Because of this, in recent years, cultural control and biological methods including botanical pesticides have been attracting considerable interest towards disease management (Upadhyay et al 1996).

The phenylamide systemic fungicide, metalaxyl, is highly effective in controlling late blight disease of potato and tomato. However, Goodwin et al (1996) reported that populations of $P$. infestans had developed resistance to this compound in different parts of the world. Neem (Azadirachta indica A. Juss) has shown insecticidal properties as well as antifungal activity (UCONN 2002). It is a perennial tree belonging to Meliaceae family and is grown in sub tropical and tropical regions. A botanical pesticide, azadirachtin, is derived in India from neem leaves and/or seeds and is now available in different formulations of commercial products. Several tests have indicated that it has considerable promise in controlling plant diseases (Ruskin 1992). Some reports have shown that it has reduced severity of diseases like late spot and rust of groundnut (Sachan 1990) and diseases of chilli (Maharishi 1993). Mugwort (Artemisia vulgaris L) an aromatic under shrub belongs to Compositae family. It grows wild in Nepal, United States and in many countries. The plant is reported having antiseptic, repellent and fumigant properties (Regmi and Karna 1988).

Trichoderma viride Pers. Ex Fr is a common saprophytic fungus, which can antagonize and also parasitize infections of plant pathogens like Phytophthora, Pythium, Rhizoctonia and Sclerotium (Wells 1988). The other species of the fungus, T. harzianum is also reported to have high potential as a bio-control agent of plant disease (Cook and Baker 1983).

Considering the growing importance of the late blight disease and the lack of information on integrated management, the present study was undertaken to develop integrated approaches to manage this disease. These approaches were cultural controls such as manipulation of date of sowing, choice of less susceptible cultivars, minimal use of fungicides and bio-control agents.

\section{MATERIALS AND METHODS}

\section{Field Experiments}

Field experiments were conducted during the tomato growing seasons of 2000 and 2001 at the research farm of the Plant Pathology Division, Khumaltar, Nepal. The experiments were laid out in a split- split plot design with three replications (Gomez and Gomez 1984). Main plots included 2 cultivars, Pusa Ruby (semi-determinate type) and CL 1131 (determinate type). Sub-plots had two dates of planting and sub-sub-plots had five treatments (Neem, Mugwort, Trichoderma, Krilaxyl and control) in 2000 and six treatments in 2001 in which Dithane M45 was included. Each sub-plot was $2-\times 3-\mathrm{m}$ with four rows. Each row was spaced $50 \mathrm{~cm}$ apart. The distance from plot to plot was 60 $\mathrm{cm}$ and from plant to plant $30 \mathrm{~cm}$. The soil was sandy loam fertilized with a basal dose of NPK at the rate of $45-60-60 \mathrm{~kg} / \mathrm{ha}$ during land preparation. A second dose of nitrogen, $45 \mathrm{~kg} / \mathrm{ha} \mathrm{N}$, was applied as a top dressing 30 days after transplanting.

Two commercial susceptible cultivars of tomato, Pusa Ruby and CL 1131 as mentioned above were used in the experiments. Seeds of each cultivar were sown in the nursery beds on the first and third week of June and transplanted into the field on the first and the third week of July during both years. Ten plants per row and 40 plants per plot were maintained. Earthing up of the plants was done fortyfive days after transplanting. Common cultural practices were followed during the cropping period. Besides late blight other diseases, insects and weeds were also monitored inspecting plants periodically in the fields.

Fresh leaves of neem and mugwort were collected and weighed into $100 \mathrm{~g}$ batches. Each batch was then macerated with $100 \mathrm{ml}$ of water $1: 1(\mathrm{w} / \mathrm{v})$ and an extract of aqueous stock solution was 
obtained by straining through two layers of cheesecloth. The stock solution was diluted to $10 \%$ (10 $\mathrm{ml}$ stock solution $+90 \mathrm{ml}$ water) before spraying in the field.

The spray schedule commenced soon after the appearance of disease in the plots. In the first crop season, the disease was observed on 12 July 2000 in the first planting and on 15 August 2000 in the second and the first spray was applied on 14 July and 17 August 2000, respectively. In the next season, the disease was observed on 7 July 2001 in the first planting and on 20 August in the second and the first spray was done on 9 July and 22 August 2001, respectively. Subsequent sprays were performed at the interval of 7 days. Altogether, five sprays were applied during each crop period.

\section{In-vitro test}

An in-vitro test was carried out in the laboratory of Department of Plant Science, University of Connecticut (UCONN) using neem (5\% stock solution), mugwort (5\% stock solution), Krilaxyl $(0.75 \mathrm{~g} / \mathrm{L})$ and Dithane M-45 $(1.5 \mathrm{~g} / \mathrm{L})$, to determine their effects on the development of mycelium of $P$. infestans. For this test, Jharrasi B isolate of $P$. infestans from Nepal was used. Trichoderma was test in dual culture with $P$. infestans.

Preparation of Rye A Agar (RAA) amended medium

Rye A Agar medium was prepared following protocol (Caten and Jinks 1968). The final volume of media was adjusted to 1 liter with de-ionized water and poured into 4 conical flasks each containing $250 \mathrm{ml}$. The flasks were autoclaved at $121^{\circ} \mathrm{C}$ with $15 \mathrm{psi}$ for 20 minutes and allowed cool down to about $50-55^{\circ} \mathrm{C}$. Each botanical/ chemical pesticide, neem extract $(20 \mathrm{ml})$, mugwort extract $(20 \mathrm{ml})$, Krilaxyl (188 mg), Dithane M-45 (375 mg) was added to each flask and mixed thoroughly. The amended medium was then poured about $15 \mathrm{ml}$ in each $90-\times 15-\mathrm{mm}$ plastic petri plates and the control set was also prepared.

\section{Experiment setup}

The experiment was set up with five plates for each of the five treatments and replicated three times. Uniform sized agar discs $(5 \mathrm{~mm})$ from actively growing $P$. infestans culture were cut from a 10-12 days old colony. One disc was put at the center of each plate. After inoculation, the plates were sealed with parafilm and incubated at $18-20^{\circ} \mathrm{C}$ in darkness for two weeks. The colony diameter of each plate was measured on every 4 th day from the date of inoculation for 4 times. The average diameter for each treatment was calculated.

\section{Harvest}

The first harvest was done in the first and third week of September in both years. Subsequently, matured fruits were harvested regularly and weighed. The total yield per plot was calculated at the end of the experiment.

\section{DISEASE ASSESSMENT}

The first disease scoring was done on 13 July and 16 August in 2000 and 8 July and 21 August in 2001 for the first and second dates of sowing, respectively. The disease was assessed visually on leaves, stems and fruits of all 40 plants of each plot following scale 0-6 $(0=$ no blight symptom and $6=90-100 \%$ plant damage/dead, AVRDC 1996). Subsequent assessments were done on every $7^{\text {th }}$ day until total blight infestation had occurred in the control plot. In total, 6 observations were taken in each plot.

The percentage of disease for each plot was calculated using the formula of Townsend and Heuberger (1943):

$$
\begin{aligned}
& \mathrm{P}=\frac{\sum(\mathrm{n} \times \mathrm{v})}{------\times 100} \\
& 6 \mathrm{~N} \\
& \mathrm{P}=\text { Percentage of disease } \\
& \mathrm{v}=\text { Numerical value of each index } \\
& 6=\text { Total number of disease severity index }
\end{aligned}
$$

$\mathrm{n}=$ Number of plants in each index

$\mathrm{N}=$ Total number of plants 


\section{Meteorological data}

Daily air temperature, precipitation and relative humidity were collected from the meteorological station located at the Khumaltar farm close to the experimental field.

\section{Statistical analysis}

Analysis of variance (ANOVA) was performed using the Statistical Analysis System (SAS 1985) and MSTATC statistical package. The least significant difference (LSD) range test $(\mathrm{P}=0.05)$ was used for mean separation of late blight management treatments. Results from the field experiments are presented as highly significant $(\mathrm{P}<0.01)$, significant $(\mathrm{P}<0.05)$ or not significant $(\mathrm{ns})$. None of the data was transformed.

\section{RESULTS}

\section{Field experiments}

At Khumaltar, in both years, the incidence of late blight disease caused by $P$. infestans in the experimental plots was high as expected for untreated tomatoes. The plants were naturally infected with late blight. The weather data showed that the monthly mean maximum temperature ranged from $26.3-28.3^{\circ} \mathrm{C}$, minimum temperature from $13-20.8^{\circ} \mathrm{C}$, relative humidity $78.4-87.4 \%$ and total rainfall 1.8-316 $\mathrm{mm}$ during June to October 2000. These observed weather conditions were found to be quite favorable for the development of late blight disease in both seasons.

During 2000, the symptoms of late blight on the plants from the first and second date of planting were first observed on 12 July and 15 August respectively. During 2001, the symptoms appeared on 7 July and 20 August for the first and second plantings, respectively. In the beginning, water soaked lesions appeared on the lowers leaves, which progressed further, showing brownish black lesions with fluffy, white, mycelial growth under the lesions of infected leaves. Symptoms were quite prominent on leaves, stems and green fruits in the control plots.

The disease spread rapidly in a spatial pattern and its intensity increased over time. A vertical gradient of disease infection developed in the plants. As the disease progressed, lesions appeared on the middle and upper leaves. There were distinctly visible effects of fungicides and bio-pesticides compared to control in both years. Disease progress was much higher in the control plots than in the treated ones. All plants in the control plots were blighted and defoliated within three-four weeks of the disease's appearance. In the treated plots, the disease progress in the plants was much slower and the severity of disease was much less than in control plots (Figures 1 and 2). The leaves remained green and attached to the plants for a longer period until senescence.

Statistical analysis indicated that the results were highly significant at $\mathrm{P}<0.001$. Table 1 and 2 showed the mean disease index, percent of mean disease severity, yield of tomato fruit and percent increase of tomato yield over controls for 2000 and 2001 respectively. It was noted that both fungicides and bio-pesticides provided better control of the disease in the treated plots than in the control plots. Krilaxyl was most effective in controlling late blight and was significantly different from other treatments at $P=0.05$. In 2001, Dithane M-45 was included and it was also effective against the disease, and significantly different from other treatments except Krilaxyl. All three biopesticides (Neem, Artemisia and T. viride) were significantly better than controls as to the severity of disease in 2000 at $\mathrm{P}=0.05$. However, in 2001, Artemisia was at par with the control and also with other two bio-pesticides (Tables 1 and 2). There were no significant differences in effectiveness among the bio-pesticides. The effect of different treatments was supported by the results obtained from the in-vitro test (Table 3). 


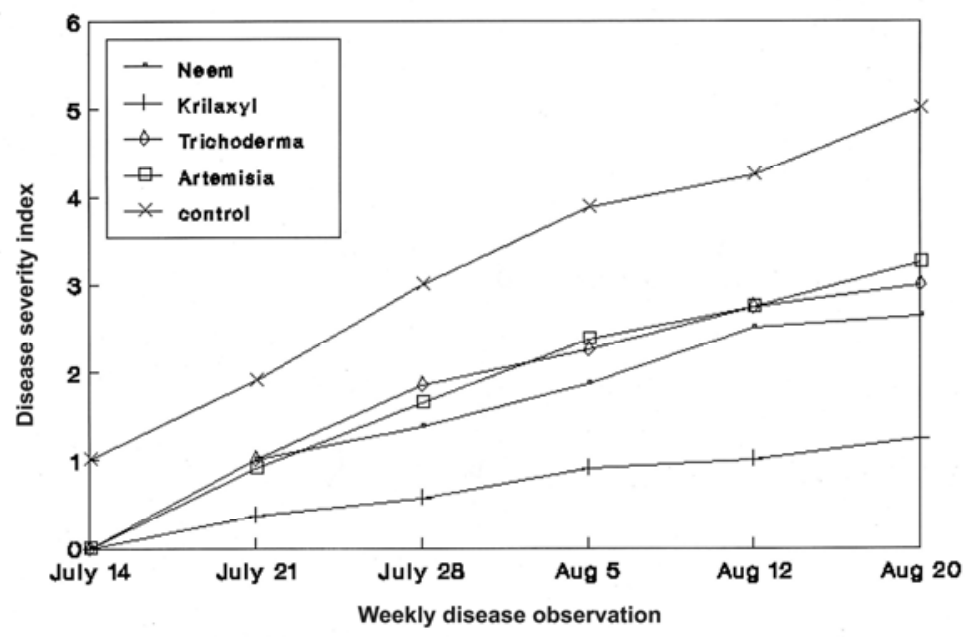

Figure 1. Effect of treatment on late blight disease progress in the first planting tomato cv. Pusa Ruby, 2000.

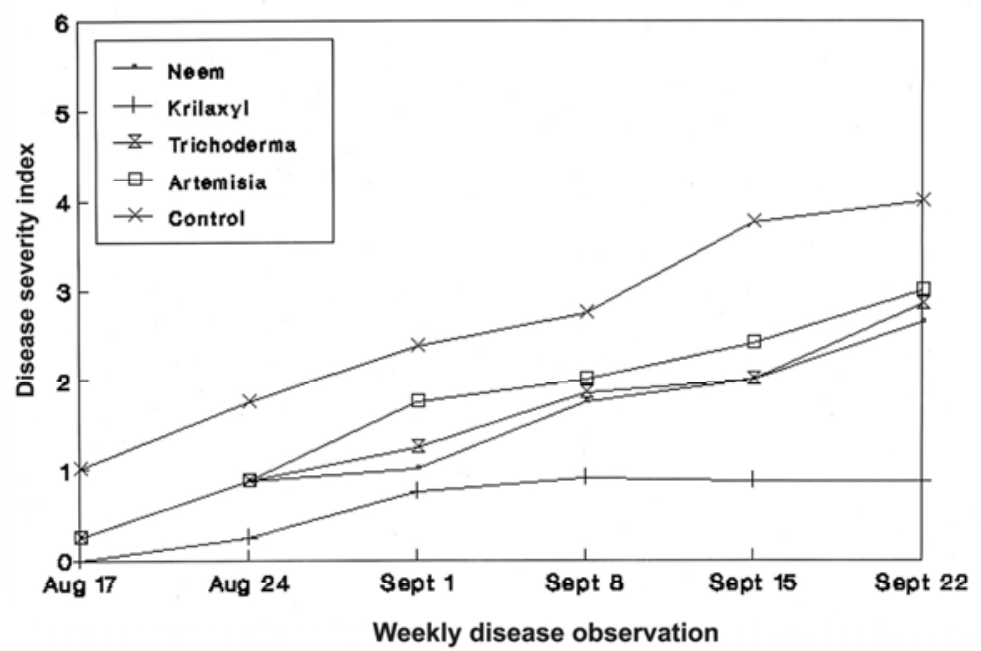

Figure 2. Effect of treatment on late blight disease progress in the second planting tomato cv. Pusa Ruby, 2000.

Table 1. Mean late blight disease index, mean disease severity, tomato fruit yield and yield increase over control at Khumaltar, Nepal, 2000

\begin{tabular}{llrrrr}
\hline SN & Treatment & $\begin{array}{r}\text { Mean disease } \\
\text { severity index } \\
(\mathrm{DSI})\end{array}$ & $\begin{array}{r}\text { Mean disease } \\
\text { severity, \% }\end{array}$ & $\begin{array}{r}\text { Tomato yield, } \\
\text { t/ha }\end{array}$ & $\begin{array}{r}\text { Yield increase } \\
\text { over control, \% }\end{array}$ \\
\hline 1 & Neem & $3.39 \mathrm{~b}$ & $56.53 \mathrm{~b}$ & $13.84 \mathrm{~b}$ & 17.49 \\
2 & Krilaxyl & $1.29 \mathrm{c}$ & $21.46 \mathrm{c}$ & $26.61 \mathrm{a}$ & 125.89 \\
3 & Trichoderma & $3.49 \mathrm{~b}$ & $58.11 \mathrm{~b}$ & $14.40 \mathrm{~b}$ & 22.24 \\
4 & Artemisia & $3.48 \mathrm{~b}$ & $58.00 \mathrm{~b}$ & $14.11 \mathrm{~b}$ & 19.78 \\
5 & Control & $4.00 \mathrm{a}$ & $66.61 \mathrm{a}$ & $11.78 \mathrm{c}$ & - \\
\hline & F-test & $* *$ & $* *$ & $* *$ & \\
& LSD at 0.05 & 0.47 & 7.90 & 1.86 & \\
& CV, \% & 18.28 & 18.24 & 13.89 & \\
\hline
\end{tabular}

Means in a column with different letters are significantly different at 0.05 level. 
Table 2. Mean late blight disease index, mean disease severity, tomato fruit yield and yield increase over control at Khumaltar, Nepal, 2001

\begin{tabular}{llrrrr}
\hline SN & Treatment & $\begin{array}{r}\text { Mean disease } \\
\text { severity index } \\
\text { (DSI) }\end{array}$ & $\begin{array}{r}\text { Mean } \\
\text { disease } \\
\text { severity, \% }\end{array}$ & $\begin{array}{r}\text { Tomato } \\
\text { yield, } \text { t/ha }\end{array}$ & $\begin{array}{r}\text { Yield increase } \\
\text { over control, } \\
\%\end{array}$ \\
\hline 1 & Neem & $3.89 \mathrm{~b}^{*}$ & $64.83 \mathrm{~b}$ & $12.12 \mathrm{c}$ & 36.49 \\
2 & Krilaxyl & $1.16 \mathrm{~d}$ & $19.38 \mathrm{~d}$ & $24.95 \mathrm{a}$ & 180.97 \\
3 & Trichoderma & $4.05 \mathrm{~b}$ & $67.50 \mathrm{~b}$ & $12.57 \mathrm{c}$ & 41.55 \\
4 & Artemisia & $4.01 \mathrm{~b}$ & $66.83 \mathrm{~b}$ & $11.20 \mathrm{~cd}$ & 26.13 \\
5 & Dithane M- & $1.79 \mathrm{c}$ & $29.81 \mathrm{c}$ & $19.28 \mathrm{~b}$ & 117.12 \\
& 45 & & & & \\
6 & Control & $4.51 \mathrm{a}$ & $75.17 \mathrm{a}$ & $8.88 \mathrm{~d}$ & \\
\hline & F-test & $* *$ & $* *$ & $* *$ & \\
& LSD at 0.05 & 0.318 & 7.15 & 2.77 & \\
& CV, \% & 11.62 & 15.90 & 22.65 & \\
\hline
\end{tabular}

Means in a column with different letters are significantly different at 0.05 level.

Table 3. Mean diameter of growth of $P$. infestans in amended rye A agar medium against pesticides and bio-pesticides in-vitro test, 2001

\begin{tabular}{|c|c|c|c|c|c|c|c|}
\hline $\mathrm{S}$ & Treatment & $\begin{array}{r}\text { Jan } 31 \\
\text { diameter, } \\
\mathrm{cm}\end{array}$ & $\begin{array}{r}\text { Feb } 4 \\
\text { diamete } \\
\mathrm{r}, \mathrm{cm}\end{array}$ & $\begin{array}{r}\text { Feb } 8 \\
\text { diamet } \\
\text { er, cm }\end{array}$ & $\begin{array}{l}\text { Feb } 12 \\
\text { diamet } \\
\text { er, cm }\end{array}$ & $\begin{array}{r}\text { Averag } \\
\mathrm{e} \\
\text { diamet } \\
\mathrm{er}, \mathrm{cm}\end{array}$ & $\begin{array}{r}\text { T-test } \\
\text { between } \\
\text { treatment and } \\
\text { control }\end{array}$ \\
\hline 1 & Neem & 0.50 & 2.17 & 4.17 & 4.87 & 2.93 & $3.826^{*}$ \\
\hline 2 & Krilaxyl & 0.10 & 0.30 & 0.50 & 0.90 & 0.450 & $3.303 *$ \\
\hline 3 & Artemisia & 0.50 & 2.40 & 4.48 & 5.42 & 3.20 & $4.256^{*}$ \\
\hline 4 & $\begin{array}{l}\text { Dithane M- } \\
45\end{array}$ & 0.10 & 0.50 & 0.80 & 1.20 & 0.650 & $3.325^{*}$ \\
\hline 5 & Control & 1.00 & 3.87 & 6.25 & 7.50 & 4.655 & - \\
\hline
\end{tabular}

*, Significant at P 0.05 .

Tables 1 and 2 also show that the tomato yield was much higher $(11-27 \mathrm{mt} / \mathrm{ha})$ in the treated plots and significantly different from the yield in control plots $(9-12 \mathrm{mt} / \mathrm{ha})$ at $\mathrm{P}=0.05$. The average increase in yield over controls was $46.4 \%$ in 2000 and $80.5 \%$ in 2001 . Within the treatments, the total yield in Krilaxyl treated plots was much higher $(25-27 \mathrm{mt} / \mathrm{ha})$ and significantly different from other treatments at $\mathrm{P}=0.05$ in both years. This was followed by Dithane M-45 (19 t/ha) and biopesticides (11-14 t/ha). The yield among the bio-pesticides was not significantly different. The relationship between fruit yield and disease severity was calculated by using the Pearson Product Moment correlation efficient and a linear regression model. A highly significant negative correlation $(r=-0.641)$ and $(r=-0.820)$ between disease severity and fruit yield was observed in 2000 and 2001 respectively. Based on regression analysis, for an increase of one disease severity index of late blight, yield loss incurred was about $4.0 \mathrm{t} / \mathrm{ha}$ in both years (Figures 3 and 4).

With in-vitro test, considerable variation in the growth rate of the $P$. infestans was observed. No mycelial growth was observed on the medium containing Krilaxyl and Dithane M-45. The colony diameter on twelfth day of inoculation was $4.87 \mathrm{~cm}$ in Neem and $5.42 \mathrm{~cm}$ in Artemisia, which were less than $7.5 \mathrm{~cm}$ in the control (Table 3). 
In the case of dual culture of Trichoderma and P. infestans, the colony diameter of $T$. viride was comparatively greater than $P$. infestans. After one week of inoculation, $T$. viride stopped and overlapped the colony of $P$. infestans. It indicates that $T$. viride inhibits the growth of $P$. infestans (not shown in the Table 3).

In both seasons, measurements of disease severity in the cultivar, Pusa Ruby, appeared slightly higher than in CL1131, but statistically there were no significant differences in the disease severity and tomato yield between the cultivars at $\mathrm{P}=0.05$ (Table 4). The incidence of late blight disease and the tomato yield from the two dates of planting were analyzed. The mean disease severity index in the first date of planting was higher and significantly different from the second date in both years. The effect of disease was negative on the yield. Consequently, the mean yield in the second date of planting was higher and significantly different from the first date in the both years at $\mathrm{P}=0.05$ (Table $5)$.

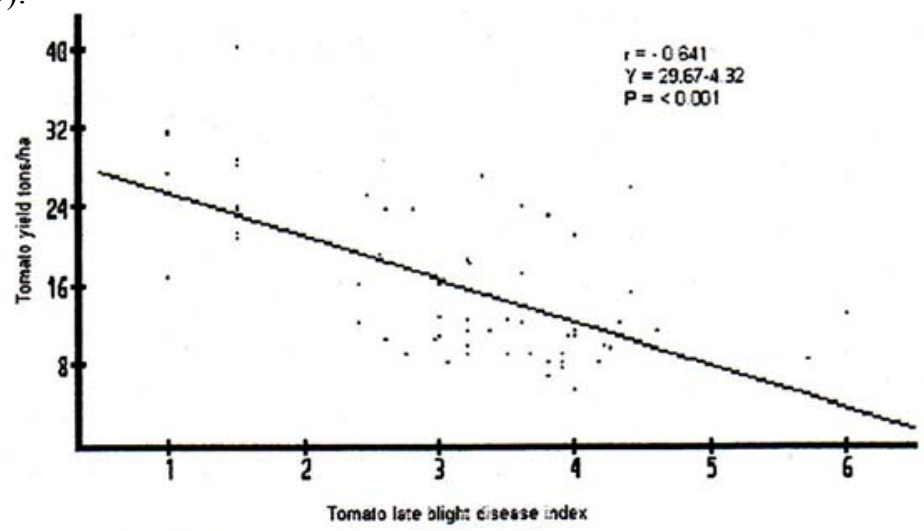

Fig. 3. Relationship between tomato fruit yield and late blight disease severity, 2000.

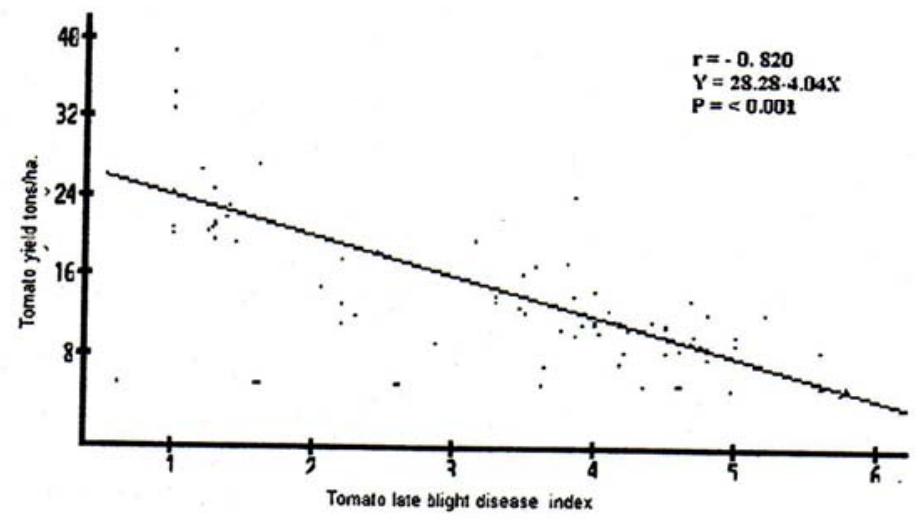

Fig.4. Relationship between tomato fruit yield and late blight disease severity, 2001 
Table 4. Separation of means between tomato cultivars against ate blight severity and tomato yield in the experimental years, 2000 and 2001

\begin{tabular}{|c|c|c|c|c|c|}
\hline \multirow[t]{2}{*}{$\mathrm{SN}$} & \multirow[t]{2}{*}{ Cultivars } & \multicolumn{2}{|c|}{2000} & \multicolumn{2}{|c|}{2001} \\
\hline & & $\begin{array}{l}\text { Mean disease } \\
\text { severity index }\end{array}$ & $\begin{array}{l}\text { Mean tomato } \\
\text { yield, } \mathrm{t} / \mathrm{ha}\end{array}$ & $\begin{array}{l}\text { Mean disease } \\
\text { severity index }\end{array}$ & $\begin{array}{l}\text { Mean tomato } \\
\text { yield, } \mathrm{t} / \mathrm{ha}\end{array}$ \\
\hline 1 & $\begin{array}{l}\text { Pusa } \\
\text { Ruby }\end{array}$ & $3.22 \mathrm{a} *$ & $17.91 \mathrm{a}$ & $3.34 \mathrm{a}$ & $15.80 \mathrm{a}$ \\
\hline 2 & $\begin{array}{l}\text { CL1 } 131 \\
\text { LSD at } \\
0.05\end{array}$ & $\begin{array}{l}3.03 \mathrm{a} \\
0.8724\end{array}$ & $\begin{array}{l}14.38 \mathrm{a} \\
4.373\end{array}$ & $\begin{array}{l}3.31 \mathrm{a} \\
0.4636\end{array}$ & $\begin{array}{l}13.89 \mathrm{a} \\
2.54\end{array}$ \\
\hline
\end{tabular}

*, Means in a column with same letters are not significantly different at 0.05 level.

Table 5. Separation of means between the dates of tomato sowing against ate blight severity and tomato yield in the experimental years, 2000 and 2001

\begin{tabular}{llllll}
\hline SN & $\begin{array}{l}\text { Date of } \\
\text { sowing }\end{array}$ & $\begin{array}{l}2000 \\
\text { Mean } \\
\text { disease } \\
\text { severity }\end{array}$ & $\begin{array}{l}\text { Mean tomato } \\
\text { yield, t/ha }\end{array}$ & $\begin{array}{l}\text { Mean } \\
\text { disease } \\
\text { severity }\end{array}$ & $\begin{array}{l}\text { Mean tomato } \\
\text { yield, t/ha }\end{array}$ \\
& & $\begin{array}{l}\text { index } \\
\text { index }\end{array}$ & \\
1 & First & $3.47 \mathrm{a}^{*}$ & $12.47 \mathrm{~b}$ & $3.68 \mathrm{a}$ & $12.57 \mathrm{~b}$ \\
2 & Second & $2.79 \mathrm{~b}$ & $19.82 \mathrm{a}$ & $2.96 \mathrm{~b}$ & $17.12 \mathrm{a}$ \\
& LSD at 0.05 & 0.365 & 4.547 & 0.464 & 2.540 \\
\hline
\end{tabular}

*, Means in a column with different letters are significantly different at 0.05 level.

\section{DISCUSSION}

Tomato late blight disease ( $P$. infestans) has become one of the most important constraints for successful cultivation of tomato in Nepal. In recent years, the frequency and severity of late blight epidemics in tomato crops has increased in tomato growing countries. Most commercial tomato cultivars are found to be susceptible to late blight. As a result, growers have been intensively using various chemical fungicides to control the disease. Today, it is environmentally, economically and scientifically unacceptable to rely primarily on fungicides for disease control. To minimize the use of fungicides against late blight disease, attempts are being made to develop integrated approaches to disease management. In the present study, different bio-pesticides extracted from Neem, Mugwort and Trichoderma were tested along with the chemical fungicides, Krilaxyl and Dithane M-45. Although these bio-pesticides were less effective than chemicals but they were found potential to provide some control of the pathogen. With applications of these bio-pesticides, yields were increased by 17 to $41 \%$ over controls. So far, there are apparently no other reports on these biopesticides being used in controlling late blight disease on tomato. Further testing of these biopesticides is needed to investigate the effect of concentration and ecological regions on their ability to control the pathogen. As these bio-pesticides become commercially available, their application in the field will be less expensive and more environmentally sound. Besides, these bio-pesticides may help to reduce application of some chemical pesticides.

Although metalaxyl is quite effective against late blight disease of tomato, the pathogen, $P$. infestans may soon develop resistance to this compound if it is solely used. There are some reports on using metalaxyl in combination with other protective fungicides to avoid the risk of developing resistance by pathogens. Gisi and Cohen (1996) reported that use of fungicide mixtures containing phenylamide compound and other protective fungicides are still an effective strategy for control of late blight of potato and tomato. Therefore in this experiment, Krilaxyl, a mixture of metalaxyl and 
mancozeb was used as one of the treatments, and found quite effective. This result was also supported by the report of Ferro (1999) who found significant reduction of disease intensity with three or more applications of metalaxyl plus manzate (Ridomill Gold MZ) in the field.

In Nepal, Krilaxyl and other fungicides containing similar ingredients have been recently introduced. Although they are effective against late blight, they are quite expensive for the common farmers. The protective fungicide, Dithane M- 45 was also found effective against tomato late blight. Therefore, if one of the tested bio-pesticides and a chemical fungicide are sprayed at least 2 times each during the cropping period, the disease may be reduced significantly. Doing so, it would help to minimize use of chemical fungicides in the field. Moreover, it would help reduce the production costs and environment pollution. However, more experiments are needed to establish the optimal number of bio-pesticides and fungicides applications with their dosage.

A second integrated approach is the manipulation of cropping patterns that has been developed to manage late blight disease. The results of this present study show that if the transplanting time is shifted 3 weeks latter than normal in rainy season, the severity of disease is significantly reduced. The reasons are probably due to less rainfall and more bright sunny days. The production and quality of tomato fruits from the latter plantings were also observed better than in the normal period. Statistically, susceptibility of Pusa Ruby and CL1131 were not different. However, the degree of susceptibility of Pusa Ruby was apparently slightly higher than in CL1131. Therefore, if the farmers like to use these cultivars for commercial cultivation, they should be advised to apply bio-pesticides to minimize the use of chemical pesticides.

In conclusion, late blight disease can be managed by rational using of bio-pesticides and fungicides. The bio-pesticides can help to reduce use of fungicides and the environmental pollution. In the rainy season, if the cropping period of tomato is shifted from early July to late July in the mid hills of Nepal, the disease intensity is reduced and also fruit yield is increased.

\section{ACKNOWLEDGEMENTS}

We would like to express our sincere appreciation to the members of Graduate Committee, Dr Sussane Von Bodman and Dr Ana Legrand, Plant Science Department, University of Connecticut for their encouragement, fruitful criticism, technical guidance and valuable suggestions. We are highly grateful to Mr Dhruva Joshi, former Executive Director, Nepal Agricultural Research Council (NARC) for his support and encouragement. We would also like to thank the faculty colleagues, staffs and field workers of the Department of Plant Science, University of Connecticut and Plant Pathology Division. NARC, Nepal for their sincere support and help. Our special thanks goes to Dr Sundar K. Shrestha, former Head of Plant Pathology Division, NARC for the permission to the first author to conduct field and laboratory research in Nepal. The first author is especially grateful to Dr Shrestha for his constant challenges and thoroughness while reviewing this paper.

\section{REFERENCES}

Caten CE and JL Jinks. 1968. Spontaneous variability of single isolates of Phytophthora infestans. I. Cultural variation. Canadian Journal of Botany 46:329-348.

CIP. 1999. Integrated control of late blight. International Potato Center (CIP). http://cipotato.org/blight/lblight.htm.

Cook RJ and KF Baker. 1983. The nature and practice of biological control of plant pathogens. The American Phytopathological Society, Minnesota.

Ferro DN. 1999. Disease control. Tomato Outdoor. 1998-1999 New England Vegetable Management Guide.

Fry WE. 1999. Potatoes, once again under fungal Attack. http://ars.usda.gov/s/pr/potato0597.htm.

Gisi U and Y Cohen. 1996. Resistance to phenylamide fungicides: A case study with Phytophthora infestans involving mating type and race structure. Annu. Rev. of Phytopathol 34:549-572. 
Gomez KA and AA Gomez. 1984. Statistical procedures for agricultural research. Second Edition. Wiley Interscience Publication, John Wiley and Sons, IRRI, Philippines.

Goodwin SB, LS Sujkowski and WE Fry. 1996. Widespread distribution and probable origin of resistance to metalaxyl in clonal genotypes of Phytophthora infestans in the United States and Western Canada. Phytopathology 86(7):793-800.

Griffith GW, R Snell and DS Shaw. 1995. Late blight (Phytophthora infestans) on tomato in the tropics. Mycologist 9:87-89.

Maharishi RP. 1993. Management of chilli (C. annuum L.) diseases by neem based preparation. In: Proceedings of World Neem Conferences, India. Pp. 809-811.

MSTATC. 1991. Microcomputer statistical program, experimental design, data management and data analysis. Michigan State University, U.S.A.

Niederhauser JS. 1991. Phytophthora infestans: The Mexican connection. In: Phytophthora (JA Lucas, RC Shattock, DS Shaw and LR Cooke, eds). Cambridge University Press, England.

Nunez J and R Voss. 2001. Late blight. Vegetable Information, University of California, Vegetable Research and Information Center. http://vric.ucdavis.edu/veginfo/topics/disease/lateblight.html.

Pohronezny K, VH Wadill, DJ Schuster and RM Sonoda. 1986. Integrated pest management for florida tomatoes. Plant Dis. 70:96-103.

Regmi PP and PL Karna. 1988. Weeds and other plants of pesticidal values in Nepal. National Conference on Science and Technology, Kathmandu, Nepal.

Reyes AA, JG Metcalf, JT Warner and LW Matheson. 1977. Outbreak of tomato late blight in Ontario. Canadian Plant Disease Survey. CAB Abstracts 57:13.

Rowe RC, SA Miller and RM Riedel. 2002. Late blight of potato and tomato. Ohio State University Extension Fact Sheet. http://ohioline.osu.edu/hyg-fact / $3000 / 3102 . \mathrm{html}$.

Ruskin FR (ed). 1992. Neem: A tree for solving global problems. Report of an Ad Hoc Panel of the Board on Science and Technology for International Development. BOSTID. National Academy Press, Washington, D.C.

Sachan GC. 1990. Pest management through neem products. Indian Farmer's Digest 22:8.

SAS. 1985. SAS/STAT User's Guide vol. I, Fourth Edition, Cary, NC.

Sherf AF and AA Macnab. 1986. Vegetable diseases and their control. A Wiley Inter Science Publication, John Wiley and Sons, New York.

Shrestha SK and K Shrestha. 1997. An epidemics of late blight of tomato. Nepalese J. of Agriculture 18-29:141-144.

Shrestha SK. 1999. Status of ate blight of potato and distribution of mating types with genetic diversity in Nepal. In: Proceedings of the Global Initiative on Late Blight (GILB) Conference, 18-19 March, Ecuador.

Stevenson WR. 1993. Management of early blight and late blight. Plant Health Management Series (RC Rowe, ed). The American Phytopathological Society.

Townsend GR and JW Heuberger. 1943. Methods for estimating losses caused by diseases in fungicide experiments. Plant Dis. Rep. 27:340-343.

UCONN. 2002. Ignoring labels on organic products can create problems. IPM. University of Connecticut (UCONN). http://www.hort.uconnedu/ipm/general/htms/orgprod.htm.

Upadhyay RK, KG Mukerji, BP Chamola and OP Dubey. 1996. Integrated pest management: Concepts and prospects. In: Integrated pest and disease management. APH Publishing Corporation, New Delhi, India.

Wells HD. 1988. Trichoderma as biocontrol agent. In: Bio-control of plant diseases Vol I. (KG Mukerji and KL Garg, eds). CRC Press Inc. 